\title{
HUBUNGAN ANTARA DUKUNGAN SOSIAL DAN COPING DENGAN MAKNA HIDUP REMAJA PENYANDANG KANKER
}

\author{
Yuliana $^{1}$, Yeni Anna ${ }^{2}$, dan Roswiyani ${ }^{3}$ \\ ${ }^{1}$ Fakultas Psikologi, Universitas Tarumanagara \\ Email: yulianawawa.agem@gmail.com \\ ${ }^{2}$ Fakultas Psikologi, Universitas Tarumanagara \\ Email: yennia@fpsi.untar.ac.id \\ ${ }^{3}$ Fakultas Psikologi, Universitas Tarumanagara \\ Email: rose.pz@ gmail.com
}

\begin{abstract}
ABSTRAK
Makna hidup itu penting terutama pada remaja penyandang kanker karena motivasi utama manusia dalam hidup adalah menemukan makna hidup. Adanya coping dan dukungan sosial membantu mengembalikan rasa kontrol pribadi terhadap remaja penyandang kanker sehingga mendorong adanya keharmonisan dan kedamaian. Subyek penelitian ini terdiri dari 30 remaja penderita kanker di Jakarta Barat. Teknik sampling yang digunakan dalam penelitian ini adalah nonprobability sampling dengan jenis penarikan sampel menggunakan teknik purposive sampling dan snowball sampling. Hasil penelitian menunjukkan ada hubungan positif dan signifikan antara dukungan sosial dan coping dengan makna hidup penderita kanker remaja, dengan $\mathrm{r}=0,842$ dan $\mathrm{p}=0,000$ (dukungan sosial dengan makna hidup), $\mathrm{r}=0,324$ dan $\mathrm{p}=0,080$ (ways of coping dengan makna hidup), dan $\mathrm{r}=0,529$ serta $\mathrm{p}=0,003$ (religious coping dengan makna hidup). Hasilnya menunjukkan bahwa semakin tinggi dukungan sosial dan coping, maka semakin tinggi makna hidup seseorang, dan sebaliknya
\end{abstract}

Kata Kunci : dukungan sosial, coping, makna hidup, remaja, kanker.

\section{PENDAhULUAN} Latar Belakang

Setiap tahun penderita kanker di dunia terus bertambah (Wahyuningsih, 2012). Data dari WHO menunjukkan setiap tahun jumlah penderita kanker di dunia bertambah 6,25 juta orang dan dua pertiga dari penderita kanker di dunia berada di negara-negara yang sedang berkembang (Lubis \& Priyanti, 2009). Di Indonesia diperkirakan setiap tahunnya terdapat 100 penderita kanker yang baru dari setiap 100.000 penduduk (Lubis \& Priyanti, 2009). Berdasarkan data statistik penelitian Rumah Sakit Dharmais (dalam Anastasia et al., 2011), di Indonesia kasus kematian akibat kanker meningkat dari 4,4 persen (1990) menjadi 10 persen (2008).

Kanker merupakan penyakit mematikan bagi siapa pun, tidak terkecuali pada anak dan remaja ("Kenali 12 Kanker pada Anak, Deteksi Dini dan Pencengahannya," 2013). Perkiraan kasus baru untuk kanker pada usia anak di Indonesia adalah kurang lebih sebesar 11.000 kasus baru pertahun (Yayasan Onkologi Anak Indonesia, 2009). Menurut data Riskesdas 2007, angka kejadian kanker pada rentang usia 15-24 tahun $(0,24 \%)$ lebih banyak dibandingkan dengan usia 5-14 tahun $(0,15 \%)$ (Depkes, 2008). Khususnya Jakarta dan sekitarnya, diperkirakan terdapat 650 kasus pertahun kejadian kanker pada usia anak (dibawah 18 tahun) (Yayasan Onkologi Anak Indonesia, 2009).

Diagnosis kanker yang terjadi selama masa remaja dapat mempengaruhi proses transisi dari masa anak-anak sampai dewasa (Engvall, Cernvall, Larsson, Essen, \& Mattsson, 2011). Remaja penyandang kanker merasa ada beberapa hal yang membatasi hidup mereka, adanya rasa khawatir, 
menyakitkan dan rasa takut, serta adanya kebutuhan akan upaya yang kuat untuk dapat bertahan (Lehmann, et.al., 2014). Bagi remaja yang dihadapkan kepada kematian, proses penyesuaian diri yang tidak berhasil dapat menimbulkan depresi (Nazari et al., 2017). Hal inilah yang akhirnya menimbulkan perasaan tidak berarti dan tidak memiliki makna dalam hidupnya.

Makna hidup dinilai penting karena menurut Frankl (2004) motivasi utama manusia dalam hidup adalah menemukan makna hidup dalam kehidupannya. Latief (dalam Anastasia et al., 2011) mengemukakan bahwa orientasi terhadap penemuan makna hidup berpengaruh terhadap kesanggupan individu untuk bertahan hidup dalam situasi apapun. Hampir seluruh penyakit menimbulkan penderitaan, tetapi tidak semua penderitaan yang ditimbulkan penyakit dapat mendorong seseorang untuk mencari tahu makna hidupnya (Lubis \& Priyanti, 2009). Penyakit kronis seperti kanker dapat mendorong seseorang untuk mencari tahu makna hidupnya (Greenstein \& Breitbat, 2000). Dengan menemukan makna hidup maka seseorang merasa telah memuaskan keinginannya dalam kehidupan.

Menurut Bastaman (1996), terdapat dua faktor yang mempengaruhi makna hidup individu yaitu faktor internal dan faktor eksternal. Faktor internal tersebut berupa pola pikir, pola sikap, konsep diri, kepercayaan, ibadah dan kepribadian. Faktor eksternal yang mempengaruhi kebermaknaan hidup individu adalah pekerjaan, pengalaman, hubungan keluarga, kebudayaan, dan lingkungan sosial. Menurut WHO (dalam Putrianti, 2013) dukungan psikologis dapat meningkatkan kualitas dan makna hidup bagi pasien dengan penyakit mengancam jiwa (Life Threatening Conditions). Salah satu bentuk dukungan psikologis yang dapat diberikan adalah dukungan sosial (Putrianti, 2013).

Caplan (dalam Suseno \& Sugiyanto, 2010) mengungkapkan bahwa dukungan sosial adalah tindakan menolong orang lain dan ketenteraman berkomunikasi dengan orang lain. Dukungan sosial merupakan variabel lingkungan yang mempunyai hubungan yang positif dengan kesehatan (Pramudiani, Hardjanto, \& Hadriami, 2001). Harter, Heath, dan McLaughlin (dalam Deutsch \& Hirsch, 2002) mengungkapkan bahwa dukungan sosial penting bagi remaja untuk membantunya menghadapi potensi konflik peran. Persepsi akan tingginya dukungan sosial dapat membantu remaja dan dewasa muda kanker mengatasi penyakitnya dan mengatasi perasaan kesendirian (Zebrack, Chesler, \& Penn, 2007).

Dukungan sosial terbagi ke dalam lima bentuk (Sheridan \& Radmacher, 1992 ; Sarafino, 2002 ; \& Taylor, 1999), yaitu: (a) dukungan instrumental (tangible or instrumental support), merupakan penyediaan materi yang dapat memberikan pertolongan langsung seperti pinjaman uang, pemberian barang, makan serta pelayanan, (b) dukungan informasional (informational support), melibatkan pemberian informasi, pengetahuan, petunjuk, saran, atau umpan balik tentang situasi dan kondisi individu, (c) dukungan emosional (emotional support), melibatkan rasa empati, ada yang selalu mendampingi, adanya suasana kehangatan, dan rasa diperhatikan akan membuat individu memiliki perasaan nyaman, yakin, dipedulikan, dan dicintai oleh sumber dukungan sosial sehingga individu dapat menghadapi masalah dengan lebih baik, (d) dukungan pada harga diri (esteem support), berupa penghargaan positif pada individu, pemberian semangat, persetujuan pada pendapat individu dan perbandingan yang positif dengan individu lain, (e) dukungan dari kelompok sosial (network support), akan membuat individu merasa menjadi anggota dari suatu kelompok yang memiliki kesamaan minat dan aktivitas sosial dengan kelompok. 
Park dan Folkman (dalam Gibson, Pessin, McLain, Shah, \& Breitbart, 2004) meninjau makna hidup dalam kaitannya dengan coping stres dan peristiwa traumatis. Park dan Folkman juga mendeskripsikan makna hidup sebagai orientasi umum dalam kehidupan, penilaian penting individu, atribusi kausalitas, mekanisme coping, dan hasil dari coping. Menurut Lazarus (dalam Niam, 2009), coping merupakan cara-cara individu dalam menghadapi situasi yang menekan. Cara mengatasi masalah setiap individu bergantung pula pada cara pandang atau penilaian terhadap masalah yang dihadapi (Jatmika, 2012). Wardani (2009) mengungkapkan bahwa jika individu dapat menggunakan copingnya dengan baik maka individu dapat melakukan penyesuaian sosial dengan baik pula.

Lazarus (dalam Effendi \& Tjahjono, 1999) membedakan perilaku coping menjadi problem focused coping dan emotion focused coping. Problem focused coping adalah usaha nyata berupa perilaku individu untuk mengatasi masalah, tekanan, tantangan dengan mengubah kesulitan hubungan dengan lingkungan. Sedangkan, emotion focused coping merupakan upaya untuk mencari dan memperoleh rasa nyaman, serta memperkecil tekanan yang dirasakan. Kemudian, Pargament (dalam Nelson, 2009) mengungkapkan adanya religious coping dalam pemecahan masalah. Mahoney, Pandleton, dan Ihrke (2006) mendefinisikan religious coping sebagai usaha untuk mengontrol situasi dengan cara spiritual atau kerohanian.

Coping dan dukungan sosial penting bagi remaja penyandang kanker. Adanya coping dan dukungan sosial dapat membantu mengembalikan rasa kontrol pribadi khususnya pada kanker dan umumnya pada kehidupan, sehingga dapat mendorong adanya keharmonian dan kedamaian (Jim, Richardson, Golden-Kreutz, \& Andersen, 2006). Oleh sebab itu, peneliti ingin mengetahui hubungan antara dukungan sosial dan coping dengan makna hidup remaja penyandang kanker.

\section{Rumusan Masalah}

Apakah ada hubungan antara dukungan sosial dan coping dengan makna hidup remaja penyandang kanker?

\section{METODE PENELITIAN}

Karakteristik partisipan pada penelitian ini adalah remaja laki-laki dan perempuan penyandang kanker yang berada pada rentang usia 12-20 tahun. Partisipan penelitian berdomisili di Jakarta dan telah menderita kanker paling lama 5 tahun terakhir. Pada penelitian ini, sampel yang digunakan berjumlah 30 orang. Teknik sampling yang digunakan dalam penelitian ini adalah nonprobability sampling dengan jenis penarikan sampel menggunakan teknik purposive sampling dan snowball sampling.

\section{Alat Ukur Dukungan Sosial}

Alat ukur dukungan sosial terdiri dari 38 butir item yang terdiri dari 19 butir negatif dan 19 butir positif. Dalam penelitian ini, skala dukungan sosial disusun berdasarkan 5 aspek dukungan sosial menurut Sheridan, Radmacher, Sarafino, dan Taylor yaitu dukungan instrumental, informasional, emosional, dukungan pada harga diri, dan dukungan dari kelompok sosial. Skala yang digunakan adalah skala Likert dengan 5 alternatif jawaban yaitu: Sangat Setuju, Setuju, Ragu-Ragu, Tidak Setuju, dan Sangat Tidak Setuju. Koefisien reliabilitas alat ukur dukungan sosial ini adalah berkisar 0,612 hingga 0,874 . 


\begin{abstract}
Alat Ukur Coping
Untuk mengukur coping pada penelitian ini menggunakan alat ukur The Ways of Coping Questionnaire (WCQ) yang dikembangkan oleh Lazarus dan Folkman. WCQ memiliki 66 butir pernyataan yang terdiri dari 8 dimensi yaitu planful problem solving, distancing, confrontive coping, seeking social support, accepting responsibility, self controlling, escape-avoidance, dan positive reappraisal. Skala pada alat ukur ini menggunakan 4 alternatif jawaban yaitu: 0 (Tidak Pernah Melakukan), 1 (Kadang-kadang Melakukan), 2 (Sering Melakukan), dan 3 (Selalu Melakukan). Koefisien reliabilitas setiap dimensi berkisar antara 0,460 hingga 0,812.

Selain alat ukur WCQ, penelitian ini juga menggunakan alat ukur Religious Coping (RCOPE) yang dikembangkan oleh Kenneth Pargament dan diadaptasi sendiri oleh peneliti berdasarkan teori dari Pargament. Religious coping terdiri dari 2 jenis yaitu negative religious coping dan positive religious coping. Koefisien reliabilitas RCOPE adalah berkisar 0,544 hingga 0,908.
\end{abstract}

\title{
Alat Ukur Makna Hidup
}

Pada penelitian ini digunakan adaptasi alat ukur dari Crumbaugh dan Maholick yaitu The Purpose in Life Test (PIL Test) yang berisi 20 butir pernyataan dengan uni dimensi. Skala pengukuran yang digunakan adalah skala sistematik diferensial. Koefisien reliabilitas PIL Test sebesar 0,968.

\section{HASIL DAN PEMBAHASAN}

\section{Gambaran Demografi Responden}

Penelitian ini dilakukan pada 30 remaja penyandang kanker di Jakarta Barat. Gambaran responden dapat dilihat dari aspek jenis kelamin, usia, lama sakit, dan jenis kanker. 
Tabel 1. Gambaran Demografi Responden Penelitian

\begin{tabular}{cccc}
\hline & Aspek & Jumlah & Persentase \\
\hline Jenis Kelamin & Laki-laki & 13 & 43,3 \\
& Perempuan & 17 & 56,7 \\
& Total & 30 & 100 \\
\hline Usia & $12-14$ tahun & 8 & 26,7 \\
& $15-17$ tahun & 10 & 33,3 \\
& $18-20$ tahun & 12 & 40,0 \\
& Total & 30 & 100 \\
\hline Lama Sakit & $<1$ tahun & 3 & 10,0 \\
& $1-3$ tahun & 26 & 86,7 \\
& $>3$ tahun & 1 & 3,3 \\
& Total & 30 & 100 \\
\hline Jenis Kanker & Kanker Darah & 17 & 56,7 \\
& Kanker Tulang & 3 & 10,0 \\
& Kanker Payudara & 2 & 6,7 \\
& Kanker Prostat & 1 & 3,3 \\
& Kanker Getah Bening & 5 & 16,7 \\
& Kanker Pangkreas & 1 & 3,3 \\
& Rabdomio Sarkoma & 1 & 3,3 \\
& Total & 30 & 100 \\
\hline
\end{tabular}

Dari tabel 1 dapat dilihat bahwa penelitian ini diikuti oleh $56 \%$ responden perempuan dengan persentase usia responden terbesar berada pada rentang usia 18-20 tahun yaitu sebesar 40\%. Mayoritas responden telah menderita sakit kanker dalam rentang 1-3 tahun yaitu sebesar 86,7\% dan jenis kanker terbanyak yang diderita responden adalah kanker darah sebesar 56,7\%.

\section{Gambaran Dukungan Sosial Responden}

Dalam penelitian ini, untuk melihat gambaran dukungan sosial yang diterima oleh responden menggunakan nilai rata-rata (mean). Alat ukur ini memiliki mean hipotetik yaitu 3. Sekor mean empiric lebih besar dibandingkan skor mean hipotetik dengan demikian rata-rata dukungan sosial diperoleh responden untuk setiap dimensi dukungan sosial dapat dikatakan tinggi. Berikut merupakan uraian gambaran dukungan sosial yang diterima oleh responden seperti yang terlihat pada tabel 2 .

Tabel 2. Gambaran Dukungan Sosial

\begin{tabular}{lccccc}
\hline \multicolumn{1}{c}{ Dimensi } & $\boldsymbol{N}$ & Minimum & Maximum & Mean & SD \\
\hline Dukungan Instrumental & 30 & 2,40 & 5,00 & 3,6467 & 0,65112 \\
Dukungan Informasional & 30 & 1,33 & 4,50 & 3,6833 & 0,73936 \\
Dukungan Emosional & 30 & 2,25 & 5,00 & 3,7958 & 0,72478 \\
Dukungan pada Harga Diri & 30 & 1,86 & 4,43 & 3,4714 & 0,76899 \\
Dukungan Kelompok Sosial & 30 & 1,5 & 4,62 & 3,2917 & 0,87119 \\
\hline
\end{tabular}


Berdasarkan data yang diperoleh mengenai dukungan sosial, dimensi dukungan sosial yang paling kecil diterima oleh responden adalah dukungan pada harga diri, dan dimensi dukungan sosial yang paling besar diterima oleh responden adalah dukungan emosional.

\section{Gambaran Cara Coping Responden}

Dalam penelitian ini, untuk melihat gambaran ways of coping yang dimiliki oleh responden menggunakan nilai rata-rata (mean). Alat ukur ini memiliki mean hipotetik yaitu 1.5. Sekor mean empiric lebih besar dibandingkan skor mean hipotetik dengan demikian rata-rata cara coping yang dilakukan oleh responden untuk setiap dimensi coping dapat dikatakan tinggi. Berikut merupakan uraian gambaran cara coping yang dilakukan oleh responden seperti yang terlihat pada tabel 3.

Tabel 3. Gambaran Cara Coping

\begin{tabular}{lccccc}
\hline \multicolumn{1}{c}{ Dimensi } & N & Minimum & Maximum & Mean & SD \\
\hline Planful Problem Solving & 30 & 0,78 & 2,67 & 1,7593 & 0,51795 \\
Distancing & 30 & 0,00 & 2,50 & 1,5667 & 0,56663 \\
Confrontive & 30 & 0,25 & 2,50 & 1,4417 & 0,61126 \\
Seeking Social Support & 30 & 0,20 & 2,60 & 1,6133 & 0,64098 \\
Accepting Responsibility & 30 & 0,00 & 3,00 & 1,6667 & 0,94077 \\
Self Controlling & 30 & 0,43 & 2,57 & 1,6095 & 0,54744 \\
Escape Avoidance & 30 & 0,40 & 2,70 & 1,4633 & 0,53400 \\
Positive Reappraisal & 30 & 0,75 & 2,75 & 1,8000 & 0,54099 \\
\hline
\end{tabular}

Berdasarkan data yang diperoleh mengenai cara coping, dimensi cara coping yang paling rendah dilakukan oleh responden adalah confrontive, dan dimensi cara coping yang paling tinggi dilakukan oleh responden adalah accepting responsibility.

Selain cara coping, penelitian ini juga melihat gambaran religious coping yang dimiliki oleh subyek dengan menggunakan nilai rata-rata. Alat ukur ini memiliki mean hipotetik yaitu 3. Sekor mean empiric lebih besar dibandingkan skor mean hipotetik dengan demikian rata-rata religious coping yang dilakukan oleh responden untuk setiap dimensi religious coping dapat dikatakan tinggi. Berikut merupakan uraian religious coping yang dilakukan oleh responden seperti yang terlihat pada tabel 4.

Tabel 4. Gambaran Religious Coping

\begin{tabular}{lccccc}
\hline \multicolumn{1}{c}{ Dimensi } & N & Minimum & Maximum & Mean & SD \\
\hline Negative Religious Coping & 30 & 1,71 & 4,13 & 3,2097 & 0,68512 \\
Positive Religious Coping & 30 & 1,88 & 4,67 & 3,6942 & 0,55709 \\
\hline
\end{tabular}

\section{Gambaran Makna Hidup Responden}

Alat ukur ini memiliki mean hipotetik yaitu 3. Sekor mean empiric lebih besar dibandingkan skor mean hipotetik dengan demikian rata-rata makna hidup yang dimiliki oleh responden dapat dikatakan tinggi. Berikut merupakan uraian makna hidup yang dimiliki oleh responden seperti yang terlihat pada tabel 5. 
Tabel 5. Gambaran Makna Hidup Responden

\begin{tabular}{lccccc}
\hline & $\boldsymbol{N}$ & $\begin{array}{c}\text { Minimu } \\
\text { Maximu }\end{array}$ & $\begin{array}{c}\text { Mean } \\
\boldsymbol{m}\end{array}$ & $\boldsymbol{S D}$ \\
\hline Makna Hidup & 30 & 1,25 & 4,85 & 3,5333 & 1,06337 \\
\hline
\end{tabular}

Berdasarkan hasil uji one sample K-S, telihat bahwa pada variabel dukungan sosial, ways of coping, religious coping, dan makna hidup penyebaran data yang ada terdistribusi normal. Hal tersebut dapat diketahui melalui nilai p pada pengujian Kolmogorov-Smirnov yang lebih besar dari 0,05. Hasil lebih lengkap dapat dilihat pada tabel 2.

Tabel 2. Hasil Uji Normalitas Variabel Dukungan Sosial, Ways of Coping, Religios Coping, dan Makna Hidup

\begin{tabular}{ccc}
\hline Variabel & Kolmogorov-Smirnov Z & P \\
\hline Dukungan sosial & 0,575 & 0,896 \\
Ways of Coping & 0,801 & 0,542 \\
Religious Coping & 0,624 & 0,831 \\
Makna Hidup & 1,130 & 0,156 \\
\hline
\end{tabular}

Berdasarkan hasil pengujian di atas, sebaran data untuk setiap variabel yang ada adalah normal, maka penelitian ini menggunakan teknik Pearson Correlation untuk menguji hubungan antar variabel penelitian.

Tabel 3. Hasil Uji Hubungan Antar Variabel

\begin{tabular}{ccc}
\hline Hubungan Variabel & R & p \\
\hline Dukungan Sosial dengan Makna Hidup & 0,842 & 0,000 \\
Ways of Coping dengan Makna Hidup & 0,324 & 0,080 \\
Religious Coping dengan Makna Hidup & 0,529 & 0,003 \\
\hline
\end{tabular}

Berdasarkan hasil uji korelasi dengan menggunakan Pearson Correlation, diperoleh bahwa variabel dukungan sosial memiliki hubungan positif dan signifikan dengan variabel makna hidup di mana nilai $r=0,842$ dan nilai $p=0,000<0,01$. Hasil tersebut menunjukkan bahwa semakin tinggi dukungan sosial, maka semakin tinggi pula makna hidup seseorang, demikian pula sebaliknya. Hasil temuan pada penelitian ini telah sejalan dengan pernyataan Pearson (dalam Parry, 1995) yang mengungkapkan bahwa tersedianya dukungan sosial akan memberi pengalaman pada individu bahwa dirinya dicintai, dihargai, dan diperhatikan. Adanya perhatian dan dukungan dari individu lain akan menumbuhkan harapan untuk hidup lebih lama, sekaligus dapat mengurangi kecemasan individu. Sebaliknya, kurang atau tidak adanya dukungan sosial akan menjadikan individu merasa tidak berharga dan terisolasi.

Berdasarkan hasil analisa variabel dukungan sosial diperoleh bahwa dukungan emosional merupakan dimensi yang memiliki nilai tertinggi dibandingkan dengan dimensi lainnya. Hasil analisa data ini 
sejalan dengan teori bahwa dukungan emosional sangat penting dalam menghadapi masalah yang tidak dapat dikontrol (Sarafino, 1998). Remaja penyandang kanker sangat membutuhkan dukungan berupa rasa empati, pendampingan dari orang-orang terdekat, suasana kehangatan, dicintai, dan diperhatikan. Dukungan-dukungan tersebut membantu remaja kanker untuk menghadapi penyakit kanker yang dapat berakhir dengan kematian.

Kemudian, variabel ways of coping tidak memiliki hubungan dengan variabel makna hidup di mana nilai $r=0,324$ dan nilai $p=0,080>0,01$. Hasil temuan pada penelitian ini sejalan dengan pernyataan Lazarus dan Folkman (1984), faktor utama yang mempengaruhi kemampuan coping seseorang adalah kesehatan dan energi (keadaan fisik), keyakinan positif (keadaan psikologis), kemampuan pemecahan masalah, dan kemampuan sosial. Seseorang yang sehat secara fisik akan memiliki kemampuan coping yang lebih baik. Lazarus dan Folkman (1984) mengatakan, "seseorang yang rapuh, sakit, kelelahan, atau lemah memiliki energi yang lebih sedikit untuk mencurahkan energinya untuk coping dibandingkan orang yang lebih sehat" (hal. 159). Dengan demikian, penyakit kanker yang dialami oleh subyek penelitian mempengaruhi kemampuan dan cara coping dalam menyelesaikan masalahnya.

Pada analisa data variabel ways of coping menunjukkan bahwa dimensi confrontive merupakan dimensi dengan nilai terendah, dan dimensi positive reappraisal merupakan dimensi dengan nilai tertinggi dibandingkan dimensi-dimensi lainnya. Srategi confrontive coping merupakan salah satu strategi dari problem-focused coping (Martz dan Livneh, 2007, p.41). Positive reappraisal merupakan salah satu strategi dari emotion-focused coping. Emotion-focused coping merujuk pada usaha untuk mengurangi emosi negatif yang muncul sebagai respon terhadap situasi mengancam dengan cara mengubah interpretasi dari situasi yang mengancam tersebut (Lazarus dan Folkman, 1984). Hasil penelitian ini menunjukkan bahwa emotion-focused coping lebih baik untuk digunakan untuk mengatasi penyakit kanker dibandingkan problem-focused coping.

Selanjutnya, variabel religious coping memiliki hubungan yang positif dan signifikan dengan variabel makna hidup di mana nilai $r=0,529$ dan nilai $p=0,003<0,01$. Hasil tersebut menunjukkan bahwa semakin tinggi religious coping, maka semakin tinggi pula makna hidup seseorang, demikian pula sebaliknya. Hal ini selaras dengan penyataan Bastaman (1996) bahwa kepercayaan (corak penghayatan) dan ibadah termasuk dalam faktor internal yang mempengaruhi makna hidup. Kepercayaan atau corak penghayatan berkaitan dengan bagaimana remaja kanker menyakini dan menghayati kebenaran, kebajikan, keindahan, keadilan, keimanan, dan nilai-nilai lain yang dianggap berharga. Melalui ibadah, remaja kanker dapat merasakan perasaan tentram. Menjalani hidup sesuai tuntunan agama akan memberikan kebahagiaan dan kebermaknaan hidup.

Positive religious coping berkaitan dengan hasil yang bermanfaat atau berguna, dan negative religious coping atau nonreligious coping berkaitan dengan hasil yang lebih buruk (Nelson, 2009, p.325). Hasil analisa data menunjukkan bahwa subyek pada penelitian ini memiliki nilai positive religious coping yang lebih tinggi dibandingkan dengan negative religious coping. Dapat dikatakan bahwa tingginya positive religious coping subyek penelitian meningkatkan rasa kepercayaan diri, fisik yang lebih sehat, dan makna hidup yang tinggi. Berkaitan dengan teori di atas, dapat dikatakan pula bahwa religious coping memiliki hubungan yang positif dan signifikan dengan makna hidup karena memberikan hasil yang bermanfaat yaitu makna hidup yang tinggi. Sedangkan, ways of coping tidak memiliki hubungan dengan makna hidup karena memiliki hasil yang buruk. 


\section{KESIMPULAN DAN SARAN Kesimpulan}

Berdasarkan dari hasil penelitian dari 30 responden remaja kanker di Jakarta Barat menunjukkan bahwa terdapat hubungan antara dukungan sosial dan coping dengan makna hidup remaja penyandang kanker. Semakin tinggi dukungan sosial dan coping, maka semakin tinggi pula makna hidup remaja penyandang kanker, demikian pula sebaliknya semakin rendah dukungan sosial dan coping, maka semakin rendah pula makna hidup remaja penyandang kanker.

\section{Saran}

Dukungan sosial sangat dibutuhkan oleh remaja penyandang kanker, sehingga keluarga, teman, dan kerabat remaja penyandang kanker disarankan dapat memberikan perhatian dan dukungan moril sehingga dapat meningkatkan makna hidupnya. Bagi peneliti lain, diharapkan dapat melakukan penelitian dengan tema sejenis untuk dapat mengkorelasikan dengan variabel lain seperti resiliensi, penerimaan diri, optimisme dan lain-lain sehingga kajian akan menjadi kajian yang berguna bagi remaja penyandang kanker.

\section{Ucapan Terima Kasih}

Peneliti mengucapkan terima kasih kepada satu pengurus Yayasan Onkologi Anak Indonesia yang memperkenalkan penulis kepada beberapa responden sehingga penulis dapat menemukan responden yang lebih banyak lagi dari komunitas yang ada. Penulis juga mengucapkan terima kasih kepada responden dan keluarganya yang telah bersedia meluangkan waktu untuk berpartisipasi dalam penelitian ini.

\section{REFERENSI}

Anastasia, G., Risnawaty, W., \& Lihardja, N. (2011). Proses penghayatan makna hidup dewasa madya yang menderita kanker paru. Arkhe. 16(1), 22-33.

Bastaman, H. D. (1996). Meraih hidup bermakna. Jakarta: Paramadina.

Depkes (2008). Laporan hasil riset kesehatan dasar nasional 2007. Diunduh pada September 12, 2013, dari http://www.pdfio.com/k-314627.html\#

Deutsch, N. L., \& Hirsch, B. (2002). A place to call home: Youth organizations in the lives of inner city adolescents. Dalam T. M. Brinthaupt, \& R. P. Lipka (Eds.), Understanding early adolescent self and identity: Applications and interventions (293-320). New York, NY: State University of New York Press. Diunduh pada September 19, 2013, dari http://books.google.co.id/books

Effendi, R. W., \& Tjahjono, E. (1999). Hubungan antara coping dan dukungan sosial dengan kecemasan pada ibu hamil anak pertama. Anima, 14(54), 214-227.

Engvall, G., Cernvall, M., Larsson, G., Essen, L., \& Mattsson, E. (2011). Cancer during adolescence: Negative and positive consequences reported three and four years after diagnosis. Plos One. Diunduh dari http://www.plosone.org/article/info\%3Adoi\%2F10.1371\%2Fjournal.pone.0029001 Frankl, S. L. (2004). Man's search for meaning. Dalam L. H. Dharma (Trans.). Bandung: Nuansa.

Gibson, C. A. , Pessin, H., McLain, C. S., Shah, A. D., \& Breitbart, W. (2004). The unmet need: Addressing spirituality and meaning through culturally sensitive communication and intervention. Dalam R. J. Moore, \& D. Spiegel (Eds.), Cancer, culture, and communication (281-319). New York, NY: Plenum. Diunduh pada September 19, 2013, dari http://books.google.co.id/books 
Jatmika, D. (2012). Strategi coping perempuan korban pelecehan seksual ditinjau dari tipe kepribadian "Eysenck". Jurnal Psikologi Ulayat, 1(1), 107-118.

Jim, H. S., Richardson, S. A., Golden-Kreutz, D. M., \& Andersen, B. L. (2006). Health Psychology, 25(6), 753-761.

Kenali 12 kanker pada anak, deteksi dini, dan pencegahannya. (2013). Diunduh pada Juli 3, 2013, dari http://childrengrowup.wordpress.com/2013/05/01/kenali-12-kanker-pada-anak-deteksi-dinidan-pencegahannya/

Lehman, L., Gronqvist, H., Engvall, G., Ander, M., Tuinman, M.A., Hagedoom, M., Saderman, R., Mattsson, E., \& Essen, L.V. (2014). Negative and positive consequences of adolescent cancer 10 years after diagnosis: an interview-based longitudinal study in Sweden. Psycho-Oncology, 23, $1229-1235$.

Lubis, N. L., \& Priyanti, D. (2009). Makna hidup pada penderita kanker leher rahim. Majalah Kedokteran Nusantara, 42(1), 14-19.

Nazari, B., Bakhski, S., Kaboudi, M., Dehghan, F., Ziapour, A., \& Montazeri, N.A. (2017). Comparison of quality of life, anxiety, and depression in children with cancer and healthy children. Internasional Journal of Pediatrics, 5(7), 5305 - 5314.

Nelson, J. M. (2009). Psychology, religion, and spirituality. New York, NY: Springer.

Niam, E. K. (2009). Koping terhadap stress pada mahasiswa luar jawa yang mengalami culture shock di universitas muhammadiyah surakarta. Indigenous, 11(1), 69-77.

Omari, O., Wynaden, D., Omari, H., \& Khatatbeh, M. (2017) Coping strategies adolescents with cancer: an interpretive phenomenological analysis study. Journal of Pediatric Oncology Nursing. $1-9$.

Pramudiani, D., Hardjanto, G., \& Hadriami, E. (2001). Kualitas hidup penderita penyakit jantung pasca serangan jantung ditinjau dari dukungan sosial dan interval waktu. Psikodimensia, 1(2), 118-122.

Sheridan, C. L., dan Radmacher, S. A. (1992). Health psychology: Challenging the biomedical model. Canada: John Wiley and Sons, Inc.

Suseno, M. N., \& Sugiyanto. (2010). Pengaruh dukungan sosial dan kepemimpinan transformasional terhadap komitmen organisasi dengan mediator motivasi kerja. Jurnal Psikologi. 37(1), 94-109.

Taylor, S. E. (1999). Health psychology (4th ed.). Singapore: McGraw-Hill Book Co.

Wahyuningsih, M. (2012). Jumlah penderita kanker di dunia naik 300 persen pada tahun 2030. $\begin{array}{llll}\text { Diunduh } & \text { September } & 12, & \text { 2013, }\end{array}$ http://health.detik.com/read/2012/08/30/165020/2003530/763/

Wardani, D. S. (2009). Strategi coping orang tua menghadapi anak autis. Indigenous, 11(1), 26-35.

Yayasan Onkologi Anak Indonesia. (2009). Profil yayasan onkologi anak Indonesia. Diunduh pada September 12, 2013, dari http://www.yoai-foundation.org/profil.php

Zebrack, B. J. , Chesler, M. A. , \& Penn, A. (2007). Psychosocial support. Dalam W. A. Bleyer, \& R. D. Barr (Eds.), Cancer in adolescents and young adults (375-385). New York, NY: Springer. Diunduh pada September 19, 2013, dari http://books.google.co.id/books 